\title{
POLIAMID FORGÁCSOLHATÓSÁGÁNAK VIZSGÁLATA KÍSÉRLETTERV SEGÍTSÉGÉVEL
}

\section{THE EXAMINATION OF CUTTING ABILITY OF POLYAMIDE WITH THE HELP OF DESIGN OF EXPERIMENT}

\author{
Horváth Richárd ${ }^{1}$, Drégelyi-Kiss Ágota ${ }^{2}$ \\ Óbudai Egyetem, Bánki Donát Gépész és Biztonságtechnikai Mérnöki Kar, Anyag- \\ tudományi és Gyártástechnológiai Intézet, 1081 Magyarország, Budapest, Népszin- \\ ház utca, 8 . \\ 'horvath.richard@bgk.uni-obuda.hu; \\ 2dregelyi.agota@bgk.uni-obuda.hu
}

\begin{abstract}
The development of novel engineering plastics and their use in the industry are characterized by a growing tendency nowadays. The finishing operation of the engineering plastics can be cutting. In this article the authors examined the cutting ability of a commonly used engineering plastics (polyamide) by help of design of experiment. The basic goal was creating phenomenological models, by which it can be easily estimated the surface roughness parameters $(R a, R z)$ as function of the input cutting parameters.
\end{abstract}

Keywords: polyamide, turning, design of experiment, surface roughness, phenomenological model

\section{Összefoglalás}

Új típusú műszaki mủanyagok kifejlesztése és ezek egyre szélesebb körben való felhasználása napjainkban is jól érzékelhető tendencia. A műszaki műanyagok befejező megmunkálása gyakran forgácsolással. történik. Jelen cikkben a szerzők egy általánosan használt müszaki műanyag (poliamid) forgácsolhatóságát vizsgálják kísérletterv segítségével. A kísérlet célja olyan fenomenológiai modell felállítása, mellyel az iparban gyakran használt $R a$ és $R z$ érdességi paraméterek könnyen becsülhetőek a bemenő (vizsgált) forgácsolási paraméterek függvényében.

Kulcsszavak: poliamid, esztergálás, kísérletterv, felületi érdesség, fenomenológiai model

\section{Bevezetés}

Müszaki müanyagoknak nevezzük azokat a hőre lágyuló vagy keményedő szintetikus anyagokat, amelyek alapvetően müszaki területen, szerkezeti anyagként használatosak. Többek között mechanikai szilárdságuk, villamos tulajdonságaik, alkal- massá teszik őket a hagyományos szerkezeti anyagok helyettesítésére [1]. A müszaki műanyagok befejező felületi megmunkálása gyakran történik forgácsolással. A müszaki műanyagok egyre terjedő felhasználása következtében napjainkban számos kutató foglalkozik forgácsolhatóságuk beható vizsgálatával. Ezeket a vizsgálatokat több- 
nyire célszerủ kísérletterv segítségével végzik, hiszen az alkalmasan megválasztott kísérleti paraméterek felhasználásával viszonylag kevés mérési pontból is sok információ nyerhető ki.

Kumar és társai [2] üvegszál erősítésű műanyag eszergálása során mérték a fellépő forgácsoló erőket és Taguchi módszerrel keresték annak optimumát. Nagyszámú bemenő (forgácsolási) paraméter figyelembe vételével azt vizsgálták, hogy mely paramétereknek van szignifikáns hatása a fellépő forgácsoló erőkre.

Lazarevic és társai [3] szintén Taguchi módszert alkalmaztak, hogy meghatározzák a poliamid (PA6) anyagminőség esztergálása során azokat az optimális forgácsolási paramétereket, melyekkel minimalizálható a gyártott felületek érdessége.

Hanafi és társai [4] szénszál erősítésü polimer vizsgálata során olyan prediktív modelleket állítottak fel, amelyek alkalmasak a bemenő forgácsolási paraméterek és a forgácsolási erő közötti kapcsolatot leírására.

Mata és Gaitonde [5] szintén prediktív modelleket alkalmaztak, részben erősítetlen, részben 30\% karbonszál és 30\% üvegszál erősítésű PEEK esztergálásának vizsgálatakor. Céljuk volt, hogy a forgácsolási paraméterek és a forgácsolási erő kapcsolatát leírják, valamint elemezték a karbon és üvegszál erősítés hatását a forgácsolhatóságra.

Hanafi és társai [6] szintén 30\% szénszál erősítésủ PEEK esztergálását vizsgálták, és optimalizálták a technológiai paramétereket Taguchi módszert alkalmazva. Az optimalizálás célja a minimális forgácsolási erő és a legjobb felületi érdesség elérése volt.

Jelen cikkben poliamid forgácsolhatóságának vizsgálati eredményei ismertetjük esztergálás technológiára vonatkozóan. A vizsgálatokat egy célszerüen kialakított kísérletterv segítségével végeztük,
Célunk alapvetően egy olyan fenomenológiai modell kifejlesztése volt, mellyel a technológiai tervezésben elvárt pontossággal becsülhetőek a várható felületi érdesség szokásos paraméterei $(\mathrm{Ra}$ - átlagos felületi érdesség, $\mu \mathrm{m} ; \mathrm{Rz}$ - egyenetlenség magasság, $\mu \mathrm{m})$ a bemenő forgácsolási paraméterek függvényében.

\section{Anyagok és módszerek}

\subsection{A kísérletben felhasznált eszközök}

Forgácsolási kísérleteinket poliamid (PA6) müanyagon $(\varnothing 60 \mathrm{~mm})$ végeztük. A poliamid kiváló mechanikai tulajdonságokkal rendelkező, szemikristályos, hőre lágyuló müanyag [1], terjedő felhasználását előnyös tulajdonágainak köszönheti: kiváló kopásállóság; siklási tulajdonságok; jó vegyszerállóság; megfelelő villamos tulajdonságok; az erősítetlen típusok az égést nem táplálják.

A forgácsolási kísérleteket MAZAK SUPER QUICK TURN 10MS CNC esztergán hajtottuk végre $(P \max =11 \mathrm{~kW} ; \mathrm{nmax}=$ $60001 / \mathrm{min})$.

A vizsgálatokat keményfém szerszámmal (TaeguTec TDA 6.00-3.00 K10) (1. ábra) végeztük (szerszám tartó: TaeguTec T-Clamp TTER 20 20-6).

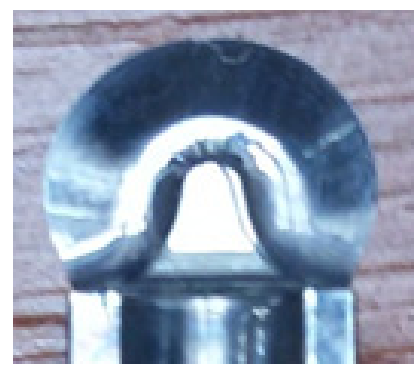

\section{1. ábra. Kisérletben alkalmazott keményfém szerszám}

Felületi érdesség mérése Mitutoyo Surftest SJ 301 müszerrel történt. A méréseket hatszor végeztünk el a hengeres munkadarab palástja mentén, $60^{\circ}$-onként (2. ábra). 


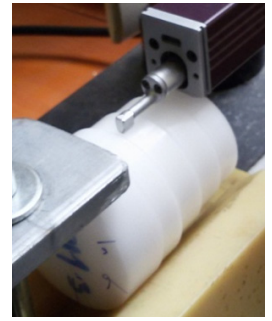

2. ábra. Poliamid felületének édesség mérése

\subsection{Az alkalmazott kísérleti módszer}

Munkánkban, a kísérletek végrehajtásához a válaszfelület módszerét (RSM) alkalmaztuk, ún. centrál kompozit kísérlettervet (CCD) valósítottunk meg, amely során a 3 bemenő faktort (forgácsolási sebesség $v_{c}$; elötolás - $f$; fogásmélység $\left.-a_{\mathrm{p}}\right) 5$ szinten változtattuk és mértük a függö változók (output adatok) értékeit $(R a, R z)$.

Kapcsolatot kerestünk a bemenő $\left(v_{c}, f\right.$, $a)$ és a kimenő paraméterek $(R a, R z)$ között az alábbi formula felhasználásával:

$$
Y=\Omega\left(v_{c}, f, a\right)
$$

A többváltozós $\Omega$ válaszfüggvényt az alábbi alakban definiáltuk:

$$
\begin{aligned}
& Y=b_{0}+b_{1} \cdot v_{c}+b_{2} \cdot f+b_{3} \cdot a+b_{11} \cdot v_{c}^{2}+b_{22} \cdot f^{2}+ \\
& +b_{33} \cdot a^{2}+b_{12} \cdot v_{c} \cdot f+b_{13} \cdot v_{c} \cdot a+b_{23} \cdot f \cdot a+\varepsilon
\end{aligned}
$$

ahol $\mathrm{b}_{0}, \mathrm{~b}_{\mathrm{i}}$ és $\mathrm{b}_{\mathrm{ij}}$ a számitott koefficiensek, $\mathrm{v}_{\mathrm{c}}, \mathrm{f}$, a bemenö paraméterek, és $\varepsilon$ a hibatag.

A három bemenő faktor szintenkénti értékeit az 1. táblázat tartalmazza.

1. táblázat. $A$ bemenö 3 faktor 5 szinten változtatva

\begin{tabular}{|c|c|c|c|}
\hline \multirow{2}{*}{ Szintek } & \multicolumn{3}{|c|}{ Faktorok } \\
\cline { 2 - 4 } & $\boldsymbol{v}_{\boldsymbol{c}}, \mathbf{m m} / \mathbf{m i n}$ & $\boldsymbol{f , ~} \mathbf{~ m m}$ & $\boldsymbol{a}, \mathbf{m m}$ \\
\hline$-1,28719$ & 100 & 0,050 & 0,50 \\
\hline-1 & 167 & 0,089 & 0,67 \\
\hline 0 & 400 & 0,225 & 1,25 \\
\hline 1 & 633 & 0,361 & 1,83 \\
\hline 1,28719 & 700 & 0,400 & 2,00 \\
\hline
\end{tabular}

A centrál kompozit terv mérési pontjait a 2. táblázat tartalmazza.
2. táblázat. A mérési pontok forgácsolási paraméterei (két centrumpontbeli ismétléssel)

\begin{tabular}{|c|c|c|c|}
\hline $\begin{array}{c}\text { Mérési } \\
\text { pontok }\end{array}$ & $\boldsymbol{v}_{\boldsymbol{c}, \mathbf{m} / \mathbf{m i n}}$ & $\boldsymbol{f}, \mathbf{m m}$ & $\boldsymbol{a}, \mathbf{m m}$ \\
\hline $\mathbf{1}$ & 167 & 0,089 & 0,67 \\
\hline $\mathbf{2}$ & 167 & 0,089 & 1,83 \\
\hline $\mathbf{3}$ & 167 & 0,361 & 0,67 \\
\hline $\mathbf{4}$ & 167 & 0,361 & 1,83 \\
\hline $\mathbf{5}$ & 633 & 0,089 & 0,67 \\
\hline $\mathbf{6}$ & 633 & 0,089 & 1,83 \\
\hline $\mathbf{7}$ & 633 & 0,361 & 0,67 \\
\hline $\mathbf{8}$ & 633 & 0,361 & 1,83 \\
\hline $\mathbf{9}$ & 100 & 0,225 & 1,25 \\
\hline $\mathbf{1 0}$ & 700 & 0,225 & 1,25 \\
\hline $\mathbf{1 1}$ & 400 & 0,050 & 1,25 \\
\hline $\mathbf{1 2}$ & 400 & 0,400 & 1,25 \\
\hline $\mathbf{1 3}$ & 400 & 0,225 & 0,50 \\
\hline $\mathbf{1 4}$ & 400 & 0,225 & 2,00 \\
\hline $\mathbf{1 5}(\mathbf{C})$ & 400 & 0,225 & 1,25 \\
\hline $\mathbf{1 6}(\mathbf{C})$ & 400 & 0,225 & 1,25 \\
\hline
\end{tabular}

\section{Eredmények}

A szignifikancia vizsgálatok elvégzését követően konstruált modellek kizárólag a szignifikáns tagokat tartalmazzák. A felületi érdesség $(\mathrm{Ra}, \mathrm{Rz})$ paramétereinek becslésére a létrehozott modell-egyenletek (2) alapján az alábbiak:

$$
\begin{gathered}
R a=0,42+2,2410^{4} \cdot v_{c}-3,87 \cdot f+0,74 a-1,52 \cdot 10^{-6} v_{c}^{2}+ \\
+11,45 \cdot f^{2}-0,36 \cdot a^{2}+1,76 \cdot 10^{-3} \cdot v_{c} \cdot f+4,99 \cdot 10^{-4} \cdot v_{c} \cdot a \\
\left(R^{2}=0,78\right) \\
R z=3,70-3,01 \cdot 10^{-3} \cdot v_{c}-19,19 \cdot f+2,728 \cdot a+ \\
+58,08 \cdot f^{2}-1,38 \cdot a^{2}+2,42 \cdot 10^{-3} \cdot v_{c} \cdot a \\
\left(R^{2}=0,71\right)
\end{gathered}
$$

A mért értékek és a számított értékek ábrázolása a mérési pontok függvényében a 3. ábrán látható.

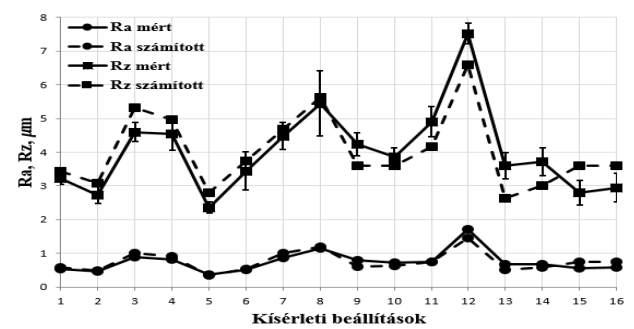

3. ábra. A mért és a számitott felületi érdességek (Ra, Rz) a mérési pontok függvényében 
A diagramból (3. ábra) kitünik, hogy a fenti egyenletekkel $(3,4)$ becsült érdességi paraméterek jól közelítik a mért értékeket. $\mathrm{Az} R a$ érdességi paraméter esetében a számított értékek illeszkedése a mért pontokra jobb, mint $R z$ paraméter esetében.

Ennek valószínü oka az, hogy a mért felületi érdesség szórása nagyobb az $R z$ paraméter esetében, mint az $R a$ esetén. Ebből adódóan az egyenletek illeszkedési pontossága is különböző mérvü, az $R a$ paramétert becslő modellé jobb.

A mért és a számított értékek közötti különbségek (a becslés hibája) normalitás vizsgálata azt mutatja, hogy a hibák várható értéke nulla körüli érték, az eltérések közel normál eloszlásúak (4. és 5. ábrák).

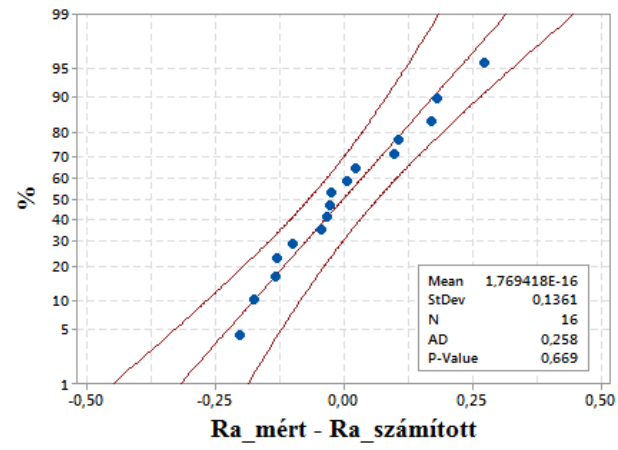

4. ábra. $\mathrm{Az}$ Ra paraméterre vonatkozó normalitás-vizsgálat eredménye

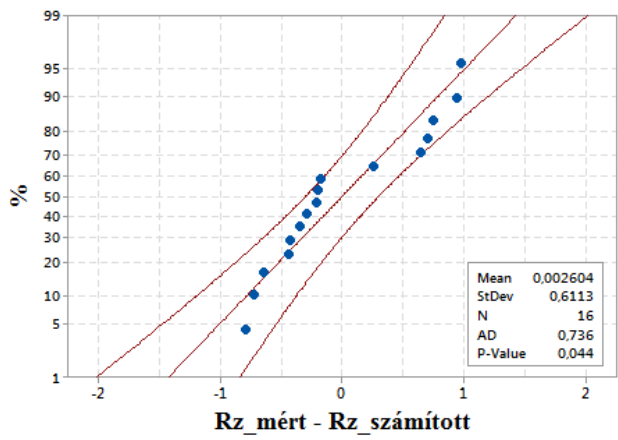

5. ábra. $A z R z$ paraméterre vonatkozó normalitás-vizsgálat eredménye

\section{Következtetések}

Vizsgáltuk a PA6 müanyag forgácsolhatóságát a gyártáskor létrejött felületi érdesség szempontjából egy alkalmasan választott kísérletterv segítségével. Következtetéseink az alábbiakban összegezhetők:

- a kísérlettervezés kiválóan alkalmazható módszer a forgácsolás-kutatásban, ugyanis viszonylag kevés számú mérésből jelentős információ mennyiség nyerhető, így a költségek csökkenthetők;

- az iparban elterjedten használatos $R a$ és $R z$ paraméterek becslésére a redukált, forgácsoló paraméterektől függő egyenleteket konstruáltunk. Ezekkel az elvárt pontossággal becsülhetők a felületi érdesség paraméterei.

\section{Szakirodalmi hivatkozások}

[1] Füzes, L., Kelemen, A.: Müszaki müanyagok zsebkönyve, Müszaki könyvkiadó, 1988

[2] Kumar, S., Gupta, M., Satsangi, P.S.: Multiple-response optimization of cutting forces in turning of UD-GFRP composite using Distance-Based Pareto Genetic Algorithm approach, Engineering Science and Technology an International Journal, 2015, 680-695.

[3] Lazarevic. D., Madic, M., Jankovic, P., Lazarevic, A.: Surface roughness minimization of polyamide pa-6 turning by taguchi method, Journal of production engineering, 2011, vol.15, 29-32.

[4] Hanafi, I., Khamlichi, A., Jabbouri, A.: Fuzzy rule based predictive model for cutting force in turning of reinforced PEEK composite, Measurement, 2011, vol. 45 [5] Mata, F., Gaitonde, V.N.: Influence of cutting conditions on machinability aspects of PEEK, PEEK CF 30 and PEEK GF 30 composites using PCD tools, Journal of materials processing technology, 2009, 19801987

[6] Hanafi, I., Khamlichi, A., Cabrera, F.M., Almansa, E., Jabbouri, A.: Optimization of cutting conditions for sustainable machining of PEEK-CF30 using TiN tools, Journal of Cleaner Production, 2012, 1-9. 